Editorial

\title{
Barriers to Implementing and Consolidating a Family Planning Program that would meet Brazilian Needs
}

\section{Barreiras à implementação e consolidação de um programa de planejamento familiar que atenda às necessidades brasileiras}

\author{
Luis Bahamondes $^{1}$ Arlete Fernandes ${ }^{1}$ Ilza Monteiro ${ }^{1}$ \\ ${ }^{1}$ Department of Obstetrics and Gynecology, Universidade Estadual de \\ Campinas, Campinas, São Paulo, Brazil \\ Rev Bras Ginecol Obstet 2017;39:373-375.
}

Around $50-55 \%$ of all births in Brazil are unplanned, and these figures include both unwanted and mistimed pregnancies. $^{1,2}$ The overall rate of induced abortion is estimated at $1.5 \%$, with all induced abortions resulting from unplanned pregnancies culminating in an adjusted abortion rate of $2.7 \%$. In many cases, unplanned pregnancies terminate in induced abortions and, since abortion in Brazil is restricted and only allowed under certain circumstances, many of these procedures are unsafe. Indeed, unsafe abortions are estimated to account for $13 \%$ of all maternal deaths. ${ }^{3,4}$

The cost of unplanned pregnancies weighs not only on the healthcare system but also on society, and involves the cost of abortion care and of unplanned childbirth. When the pregnancy is unplanned, the likelihood of preterm births and low birthweight infants increases, and this scenario implies high costs associated with neonatal care and longterm disabilities. ${ }^{5,6}$ The total fertility rate in Brazil has fallen significantly in recent decades, and today stands at 1.8 births per woman. Over the same period, the use of contraceptives has increased. ${ }^{7,8}$

Preventing unplanned pregnancies through publicly funded programs is a strategy that has proven to be effective in significantly cutting costs for health services. ${ }^{9}$ In this editorial, we will discuss the current situation in Brazil, providing an insight into the inequalities that exist in the provision of contraceptive methods, particularly long-acting reversible contraceptive (LARC) methods, and highlighting the causes and consequences of unplanned pregnancies in Brazil, where fertility planning services are vastly different to those provided in developed countries, and where abortion legislation is restrictive.

The Brazilian National Healthcare Service (SUS, in the Portuguese acronym) covers the cost of around $70-75 \%$ of all procedures performed in the country, including those related to reproduction. An estimated 1.79 million un- planned pregnancies and 1.47 million planned pregnancies occur annually, with 351 maternal deaths, of which $49(14 \%)$ are attributed to abortions, and 302 to complications resulting from miscarriages and childbirth. The number of infant deaths in the first year of life is estimated at 32,864 . The model estimates the number of preterm deliveries attributed to unplanned pregnancies at 122,523 . The estimated number of neonatal admissions associated with unplanned pregnancies was 224,631 for 2010 , including all preterm deliveries and $7.6 \%$ of all term deliveries. ${ }^{10}$

Consequently, the total annual costs attributed to unplanned pregnancies are estimated at $\mathrm{R} \$ 4.1$ billion or more, depending on the exchange rate. Approximately $\mathrm{R} \$ 4.07$ billion (99.2\%) of that total amount is attributed to childbirth and its resulting complications. Based on national cost estimates and the number of unplanned pregnancies per year, the cost per unplanned pregnancy is calculated at $\mathrm{R}$ $\$ 4,439$. However, this is based only on cases occurring within the public healthcare system, with abortions paid for by individuals or clandestine cases not being included in this calculation. This simple analysis highlights the considerable cost savings that can be achieved by reducing the number of unplanned pregnancies. ${ }^{10,11}$ There are many examples regarding the potential cost savings that can be made by preventing unplanned pregnancies. In the United States, for instance, it was estimated that every dollar spent on preventing unplanned pregnancies results in savings of US $\$ 2.76$ at 2 years and US\$5.33 at 5 years following delivery. ${ }^{10,11}$

If most unplanned pregnancies can be avoided, why is the unplanned pregnancy rate still so high in Brazil (50-55\% of all pregnancies) when contraceptive prevalence is high and the total fertility rate is in decline? The answer to this question is complex and depends on many factors. Scientific evidence shows that the most effective approach to prevent unplanned
Address for correspondence Luis Bahamondes, MD, PhD, Caixa Postal 6181, 13084-971,

Campinas, SP, Brazil

(e-mail: bahamond@caism.

unicamp.br).
DOI https://doi.org/

10.1055/s-0037-1604423. ISSN 0100-7203.
Copyright $\odot 2017$ by Thieme Revinter

Publicações Ltda, Rio de Janeiro, Brazil
License terms

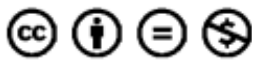


pregnancies is through education and contraceptive use, with LARC methods being the most effective intervention. ${ }^{12-16}$ Many international and national agencies and societies, including the Brazilian Federation of Associations of Gynecology and Obstetrics (FEBRASGO, in the Portuguese acronym), advocate the use of LARC methods as first-line. Long-acting reversible contraceptive methods include intrauterine contraceptives, that is, the copper intrauterine device (IUD) and the levonorgestrel-releasing intrauterine system (LNG-IUS), and subdermal implants. However, the prevalence of contraceptive use in Brazil is based on combined oral contraceptives (COCs), which are associated with a failure rate of around 8/100 women-years, and tubal ligation ${ }^{2}$, which is in decline in this country. $^{17,18}$

Conversely, the sales of LARC methods, the most effective contraceptive methods, have been very low, ${ }^{18-20}$ even during the recent Zika virus outbreak. ${ }^{21}$ This reflects the fact that most women are using contraceptive methods such as COCs, progestin-only pills, injectable and emergency contraceptives, all of which are much less effective than LARC methods. Moreover, there is an unmet need for family planning that is estimated at $8 \%$, assuming that at least 22 million women need contraception to avoid an unwanted pregnancy. It was recently calculated from current sales of contraceptives that almost 18 million women are protected; however, $90 \%$ of these are relying on methods for which the typical use effectiveness is low. ${ }^{21}$

Several barriers have been identified that may limit the uptake of LARC methods. First, there are the public policies for the provision of contraceptive methods. The Brazilian Ministry of Health recently refused FEBRASGO's request to introduce the LNG-IUS and contraceptive implants into public healthcare services, arguing that the cost of these methods is high, and that the copper IUD is available within the public sector. Even though it is true that the copper IUD is available and cheaper than the other two methods, the reality is that it is used by no more than $1.8 \%$ of women of reproductive age. This situation could remain unchanged even if the LNG-IUS and the implants were available; however, many women are unable to use the copper IUD, or do not like the method, and could benefit if the LNG-IUS and the implants were also available. On the other hand, reflecting the current situation with the copper IUD, it is possible that, even if all the LARC methods were available in the public sector, this would not necessarily increase the prevalence of the use of LARC methods or, consequently, lead to any reduction in the unplanned pregnancy rate.

The lack of training of healthcare providers in LARC placement is another factor that contributes to the low rates of use of these methods. For one thing, many medical residency teaching programs in Obstetrics and Gynecology fail to provide any training on LARC placement, while hospitals run by the Catholic Church refuse to provide any family planning methods at all. It could be argued that, in this particular case, they have the right to do so; however, why does the Brazilian Ministry of Education pay for the training of medical residents who then fail to receive adequate training in family planning, which is a human right included in the Brazilian constitution? Yet another obstacle is that the manufacturers of the LARC methods have done little to provide training to the thousands of Brazilian gynecologists.

Notwithstanding, many doctors who have actually been trained refuse to provide copper IUDs to women at basic health units. Why? In many cases, because they are overwhelmed with work and obliged to meet quotas in terms of the number of consultations they perform daily. Another common situation is the physician refusing to insert an IUD if the woman is not having her menstrual period at that time. This is a major barrier, since it is often difficult to schedule an appointment within a few days of the onset of menstruation. In other cases, doctors prescribe a COC because it is simpler than inserting an IUD, or because there is no adequate referral system in the event of complications, or even because the appropriate instruments are not available, such as a Hartman forceps to remove IUDs in cases in which the threads cannot be visualized. In addition to the difficulties involved in scheduling consultations, other barriers at service delivery points (SDPs) involve issues such as the fact that LARC methods, when available, can only be inserted by physicians, that the methods are sometimes allowed to remain on the shelves at the SDPs until their expiration date has passed, and that healthcare providers are not given updated information on the benefits and risks of LARC methods. Furthermore, there are the myths, misconceptions and misinformation that exist regarding these methods, and women's fear of pain at insertion.

The lack of reimbursement or incomplete insurance coverage for LARC methods may result in the client having to pay high up-front costs. The high cost of LARC methods has already been shown to represent an important barrier to access these methods. ${ }^{22}$ A recent study conducted in the clinic of our institution showed that providing women with the LNG-IUS at no cost proved successful in preventing unwanted pregnancies, maternal morbidity and mortality, child mortality, and unsafe abortion. ${ }^{20}$ The SUS provides free coverage to around $74 \%$ of the population, including the provision of contraceptive methods at no cost, since family planning is guaranteed under the Brazilian constitution. The LNG-IUS and the contraceptive implants, however, are not included in the contraceptive arsenal provided free of charge by the SUS, with only a few, very rare exceptions.

A new model of family planning management needs to be developed urgently. It is not right that the unplanned pregnancy rate remains high despite high contraceptive prevalence, nor that the prevalence of the use of LARC methods is low. The availability of LARC methods must be increased, as well as the access to and use of these methods. Task sharing is necessary, and a coordinated response is needed from the federal, state and municipal governments; however, governmental response alone will be insufficient. To ensure access to LARC methods, the academia must be involved, as well as professional and scientific organizations, private health insurance companies, policy makers, and all stakeholders. This editorial may serve to initiate a debate on the subject, not only in government offices but also among medical and 
nursing students, residents in Gynecology and Obstetrics and family practice, and at scientific congresses and other applicable events. Brazil urgently needs to identify an appropriate and rapid solution to reduce the high rate of unplanned pregnancies in the country and its consequences in terms of maternal morbidity and mortality, as well as the high rate of unsafe abortions.

\section{Conflicts of Interest}

The authors declare no conflicts of interest.

\section{Acknowledgments}

This editorial was supported in part by Fundação de Apoio à Pesquisa do Estado de São Paulo (FAPESP) (grant \# 2015/ 20504-9).

\section{References}

1 SantelliJ, Rochat R, Hatfield-Timajchy K, et al; Unintended Pregnancy Working Group. The measurement and meaning of unintended pregnancy. Perspect Sex Reprod Health 2003;35(02):94-101

2 Pesquisa Nacional de Demografia e Saúde da Criança e da Mulher. Banco de dados [National Demographic and Health of Children and Women: Database] [webpage on the Internet]. Ministry of Health of Brazil; 2008. Available at: http://bvsms.saude.gov.br/ bvs/pnds/banco_dados.php. Accessed on October 12, 2016

3 Unsafe Abortion: Global and Regional Estimates of the Incidence of Unsafe Abortion and Associated Mortality in 2008. 6th ed. Geneva: World Health Organization; 2011. Available at: http:// whqlibdoc.who.int/publications/2011/9789241501118_eng.pdf. Accessed on April 13, 2017

4 Vlassoff M, Walker D, Shearer J, Newlands D, Singh S. Estimates of health care system costs of unsafe abortion in Africa and Latin America. Int Perspect Sex Reprod Health 2009;35(03):114-121

5 Rocha RC, de Souza E, Soares EP, Nogueira ES, Chambô Filho A, Guazzelli CA. Prematurity and low birth weight among Brazilian adolescents and young adults. J Pediatr Adolesc Gynecol 2010;23 (03):142-145

6 Born Too Soon: The Global Action Report on Preterm Birth. Geneva: World Health Organization; 2012. Available at: http://www.who.int/ pmnch/media/news/2012/introduction.pdf. Accessed on April 14, 2017

7 Potter JE, Schmertmann CP, Assunção RM, Cavenaghi SM. Mapping the timing, pace, and scale of the fertility transition in Brazil. Popul Dev Rev 2010;36(02):283-307

8 Curtis SL. Contraceptive use dynamics research needs post fertility transition. Rev Bras Estud Popul 2012;29:191-193
9 Amaral G, Foster DG, Biggs MA, Jasik CB, Judd S, Brindis CD. Public savings from the prevention of unintended pregnancy: a cost analysis of family planning services in California. Health Serv Res 2007;42(05):1960-1980

10 Le HH, Connolly MP, Bahamondes L, Cecatti JG, Yu J, Hu HX. The burden of unintended pregnancies in Brazil: a social and public health system cost analysis. Int J Womens Health 2014; 6:663-670

11 Pesquisa revela dados sobre parto e nascimento no Brasil [Research reveals data on labor and delivery in Brazil] [webpage on the Internet]. Ministry of Health of Brazil; 2012. Available at: http://www.ensp.fiocruz.br/portal-ensp/informe/site/materia/ detalhe/29584. Accessed on April 24, 2017

12 American College of Obstetricians and Gynecologists. ACOG Committee Opinion No. 392, December 2007. Intrauterine device and adolescents. Obstet Gynecol 2007;110(06):1493-1495

13 American College of Obstetricians and Gynecologists Committee on Gynecologic Practice; Long-Acting Reversible Contraception Working Group. ACOG Committee Opinion no. 450: Increasing use of contraceptive implants and intrauterine devices to reduce unintended pregnancy. Obstet Gynecol 2009;114(06):1434-1438

14 Oringanje C, Meremikwu MM, Eko H, Esu E, Meremikwu A, Ehiri JE. Interventions for preventing unintended pregnancies among adolescents. Cochrane Database Syst Rev 2009;(04):CD005215

15 Winner B, Peipert JF, Zhao Q et al. Effectiveness of long-acting reversible contraception. N Engl J Med 2012;366(21):1998-2007

16 Facts on Abortion in Latin America and the Caribbean. New York, NY: Guttmacher Institute; 2012. Available at: http://www.guttmacher. org/pubs/IB_AWW-Latin-America.pdf. Accessed on February 18, 2017

17 Trussell J. Contraceptive efficacy. In: Hatcher RA, Trussell J, Nelson AL, Cates W, Kowal D, Policar M (eds). Contraceptive Technology: Twentieth Revised Edition. New York NY: Ardent Media; 2011

18 Bahamondes L, Bottura BF, Bahamondes MV, et al. Estimated disability-adjusted life years averted by long-term provision of long acting contraceptive methods in a Brazilian clinic. Hum Reprod 2014;29(10):2163-2170

19 Secura GM, Madden T, McNicholas C, et al. Provision of no-cost, long-acting contraception and teenage pregnancy. N Engl J Med 2014;371(14):1316-1323

20 Ferreira JM, Monteiro I, Fernandes A, Bahamondes MV, Pitoli A, Bahamondes L. Estimated disability-adjusted life years averted by free-of-charge provision of the levonorgestrel-releasing intrauterine system over a 9-year period in Brazil. J Fam Plann Reprod Health Care 2017:jfprhc-2016-101569 [Epub ahead of print]

21 Bahamondes L, Ali M, Monteiro I, Fernandes A. Contraceptive sales in the setting of the Zika virus epidemic. Hum Reprod 2017; 32(01):88-93

22 Peipert JF, Madden T, Allsworth JE, Secura GM. Preventing unintended pregnancies by providing no-cost contraception. Obstet Gynecol 2012;120(06):1291-1297 